\title{
МИСТЕЦЬКА ОСВІТА ЯК ШЛЯХ ВИХОВАННЯ ДУХОВНОСТІ
}

\author{
O.I. Шрамко
}

Истина должна быть пережита, а не преподана. .

Герман Гессе

Гуманістично-особистісна орієнтація сучасної освіти, що все більше простежується і на багатостраждальному, проте все й досі терплячому вітчизняному освітянському просторі, повертає нас до традиційних, невмирущих цінностей людського духу - цінностей, які ми називаємо духовними і узагальнюємо триєдністю Істини, Добра і Краси. Розуміння важливості й необхідності духовного камертону в нашому житті тільки перший крок на шляху «опритомнення» України, наступним кроком постає вирішення проблеми виховання духовності, яка щільно пов'язана з проблемою духовного відродження нації.

Проблема духовного відродження - найактуальніша проблема вітчизняної гуманістики, особливо з огляду на невтішні реалії сучасного життя країни. Омріяне віками духовне оновлення українського суспільства і в наш час залишається приманливою, але вельми химерною метою розвитку нації. «Розбуджена окраденою» (Л. Костенко), Україна потерпає від надзвичайної хаотичності, невизначеності та неузгодженості, якими відзначається сучасний стан буття духу України і це аж ніяк не сприяє повноцінному розгортанню процесу духовного відродження. Тому проблема виховання духовності є пріоритетною й невідкладною проблемою, що стоїть сьогодні перед освітянами країни.

Виховати духовно зрілу особистість, здатну бути повноцінним суб'єктом духовного відродження нації, - прекрасна і благородна мета,

Актуальні проблеми духовності 
але складна й відповідальна. Ї̈̈ досягнення потребує цілеспрямованості й виваженості, особливого значення при цьому набуває пошук шляхів виховання духовності як «найвищого рівня ієрархії цінностей людського світовідношення» (В.Г. Табачковський).

Мистецька освіта - один з таких шляхів, і можливо найефективніший, адже мистецтво як соціогенетичний код культури завжди було й залишається найяскравішим виразником характерних особливостей як зовнішнього вияву життя нації, так і його внутрішнього - духовного змісту. Крім того, зустріч з мистецтвом - це не просто відкриття істини, а її завжди особистісне переживання, її емоційне, а отже, більш стійке закріплення в духовному світі людини.

Не дивно, що проблема духовного відродження України та ролі мистецтва у цьому процесі хвилює сьогодні всіх небайдужих представників вітчизняної культури - науковців, митців, громадських діячів, політиків тощо і досить чітко окреслюється як в суспільно-громадській думці, так і в теоретичних наукових напрацюваннях. На терені української гуманістики це роботи Іванова В.П., Забужко О.С., Канарського А.С., Лисого І.Я., Личковах В.А., Мазепи В.І., Малахова В.А., Мойсеєва І.К., Новикової Л.І., Орлової Т.І., Поповича М.В., Шинкарука В.І., Шудрі Є.П., Шульгіної В.Д., Шульги Р.П. та ін.

Особливого значення для осмислення проблеми набувають сьогодні дослідження в галузі вітчизняного мистецтвознавства та мистецької педагогіки (Баканурський А.Г., Масол Л.М., Ничкало С.А., Падалка Г.М., Рейзенкінд Т.Й., Рудницька О.П., Семашко О.М., Щолокова О.П. та ін.). Зацікавленість різними аспектами зазначеної проблеми демонструють міжнародні, всеукраїнські, регіональні науково-практичні конференції, що проводяться в Україні: «Гуманістичні орієнтири мистецької освіти» (Київ); «Духовність українства» (Житомир); «Політичний, соціально-економічний та культурний розвиток України в роки незалежності», «Мистецько-педагогічна освіта (теорія, методи, технології) - 2006», «Сучасні освітні технології у професійній підготовці вчителя мистецьких дисциплін» (Кривий Ріг); «Державна етнонаціональна політика: правовий та культурологічний аспекти в умовах Півдня України» (Запоріжжя); «Актуальні проблеми розвитку спеціальностей мистецтв в контексті Болонського процесу» (Херсон); «Модернізація мистецької освіти у контексті євроінтеграції», «Трансформації музичної освіти і культури в Україні» (Одеса) тощо.

Все це говорить про те, що теоретичне поле вітчизняного осмислення проблеми духовного відродження України та ролі мистецтва у цьому процесі досить обширне й розмаїте, але $\epsilon$ також і малодослі- 
джені аспекти окресленої проблеми, які потребують уваги науковців. Одним з них є осмислення та обгрунтування ролі мистецької освіти у процесі виховання духовності, що й стало метою даної статті.

Завдяки гуманістичній природі мистецтво як жодна 3 форм духовного життя суспільства особливо гнучко відкликається на будьякі особисті потреби й інтереси, надає людині можливості як соціалізації, так й індивідуації. Тому звернення до мистецтва як рушійної сили духовного відродження є прерогативою вітчизняного сьогодення, спрямованого до особистості. Базується таке звернення на розумінні мистецтва як самосвідомості культури (як відомо, особливо активно такий підхід до осмислення мистецтва розробляється синергетикою і постмодернізмом), що дозволяє саме в мистецтві вбачати духовно-змістовний камертон буття культури і особистості як суб'єкта культури.

Це пов'язано, насамперед, з тим, що основною функцією мистецтва в культурі є генерація, узагальнення та відтворення духовного досвіду людини і людства. «Саме мистецтво є найінтенсивнішим засобом освоєння тезаурусу цінностей і смислів людського буття, забезпечуючи при цьому їхню конкретно-наочну репрезентацію і безпосереднє переживання сучасною людиною. Мистецтво визначає «міру небайдужості» (А.С.Канарський) до світу універсальних цінностей і смислів, $\mathrm{a}$, отже, робить культурний досвід людства частиною внутрішнього досвіду сучасної людини» [2, с. 54].

У процесі національної розбудови України особливого значення набуває усвідомлення тієї ролі, яку відіграє мистецтво у процесі духовного відродження, адже художня діяльність завжди була невід'ємною частиною духовного самотворення українського народу, в ній узагальнюється досвід нації, втілюються своєрідні стійкі риси психології українства, його моральні якості та духовні ідеали. I у цьому сенсі мистецька освіта найповніше відповідає завданням Національної доктрини розвитку освіти, яка визначає систему концептуальних ідей та поглядів на стратегію і основні напрями розвитку освіти у першій чверті XXI століття. Так, у частині III («Національний характер освіти і національне виховання») чітко зазначено, що «освіта має гуманістичний характер і грунтується на культурно-історичних цінностях українського народу, його традиціях і духовності», a «національне виховання спрямовується на залучення громадян до глибинних пластів національної культури і духовності, формування у дітей та молоді національних світоглядних позицій, ідей, поглядів і переконань...» [5, с.30-31].

У мистецтві зберігаються живодайні традиції національної культури, унікальність світобачення та світовідчуття певного народу, але, 
в той же час, мистецтво, якщо воно художньо правдиве, не може замкнутися тільки у національному, воно завжди звернуте до загальнолюдських духовних вимірів. Художня мова мистецтва, живлячись життєдайною силою і глибиною національних духовних джерел, водночас живиться і з джерела загальнолюдської культури і духовності. Тому, завжди залишаючись індивідуально-національною, вона є носієм загальнолюдського змісту.

Цей зміст знаходить своє предметне втілення у творі мистецтва, що створюється не лише з метою відображення у художньому образі внутрішнього світу художника, але значно більшою мірою з тим, щоб за допомогою цього образу піднести певну форму життя до рівня загальної цінності, цінності духовного гатунку. «... сутність художнього твору, - за висловом К. Юнга,- полягає не в його обтяженості чисто персональними особливостями - чим більше він ними обтяжений, тим менше мова може йти про мистецтво, - але у тому, що він говорить від імені духу людства, серця людства і звертається до них» [7, с. 116]. Художній твір поєднує унікально-особистісний досвід митця з досвідом людства, піднімаючи індивідуальний досвід до того ступеня узагальнення, коли він постає як вираження соціального досвіду.

На всіх рівнях свого здійснення унікально-особистісне самовираження художника наповнене соціальним змістом. I у цьому відношенні «справжня стихія живого мистецтва є буття соціальне...» [3, с. 8]. Але поворотним стрижнем, спрямовуючим вектором цього соціального буття завжди залишається індивідуальне начало, елемент «авторства», що міститься в особистісному духовному досвіді митця. «I епоха може відбитися» у цьому досвіді «як у якомусь магічному дзеркалі, що відображує її душу» [1, с. 37]. «Дзеркало» ж повинно бути чистим і неупередженим, а це можливо лише тоді, коли чутлива душа художника не просто бринить струнами духу епохи, а чує у цьому звучанні шляхетні звуки духовності як онтологічного осереддя людини з його вічними цінностями добра й віри, надії і любові.

Зрозуміло, що мистецтво є невід'ємною складовою становлення духовно розвиненої особистості, а відтак повинно бути важливим предметом ㄲï навчання і виховання вже з раннього дитинства. Залучення до художньої культури значно розширює духовні обрії людини, узагальнює ієрархію її цінностей та смислів, гармонізує внутрішній світ.

У цьому відношенні універсальна природа мистецтва надає значні можливості. Як своєрідна "філософія серця", що поєднує мудрість розуму та мудрість серця силою уяви, фантазії художника, мистецтво найвищою мірою здатне не лише сприяти пробудженню та поглиблен- 
ню людських почуттів, а й спонукає працювати думку, формує моральні принципи, розширює світогляд, укріплює ідейні позиції, породжує ідеали. Тобто, за допомогою мистецтва людина не тільки пізнає навколишню дійсність, а, насамперед, формує себе як всебічно розвинену духовну особистість, що є важливим кроком на шляху до духовності як вираження «теоретико-пізнавальної, художньо-творчої та морально-аксіологічної активності людини» (Н. Хамітов).

У цій триєдності художньо-творча активність займає особливе місце, адже завдяки художньому універсалізму здатна поєднувати і теоретико-пізнавальну, і морально-аксіологічну діяльність особистості. Це стає можливим тому, що у художньому досвіді об'єктивне й суб'єктивне, несвідоме й свідоме, чуттєво-інтуїтивне і осягнуте розумом нерозривні, неподільні і постають у взаємопроникненні.

3 точки зору виховання духовності особливо важливою $є$ моральнісна складова мистецтва, адже при всій суперечності й різноманітті поглядів на природу й сутність духовності, в сучасній філософській думці вимальовується її беззаперечна моральнісна основа, що дозволяє будувати морально-світоглядні ідентифікації духовності як «здатності переводити універсум зовнішнього буття у внутрішній всесвіт особистості на етичній основі» (С.Б. Кримський).

На моральнісну складову мистецтва звернули увагу вже давні греки, які пов'язали прекрасне і морально досконале поняттям калокагатії і висунули ідею про те, що справжнє мистецтво не може бути аморальним. Не даремно від мистецтва греки очікували духовної користі в етичному, педагогічному, політичному відношенні.

Особливою увагою у цьому сенсі користувалася музика. Вчення про музичний етос як вчення про етичне значення музики, її зв'язок 3 психікою, темпераментом та моральними здібностями людини було загальноантичним вченням і наскрізною проблемою античної естетики. I якщо музика і музичне виховання були практичною основою педагогічної теорії греків класичної епохи, то вчення про музичний етос було іiі теоретичним підгрунтям. Греки розглядали музику як найважливіший чинник впливу на моральний світ людини, як найефективніший засіб виправлення та виховання характерів, створення певної психологічної установки особистості - етосу.

Зокрема, теорія музичного виховання Платона, а пізніше і музично-естетична концепція Арістотеля будувалися на розумінні суспільного характеру музики, її виховної функції та зв' язку з громадянським етосом. Заняття ж музикою як важлива і серйозна справа, а не лише розвага, повинні були стати головною частиною державної системи ви- 
ховання і вважалися обов'язковими для всіх громадян. Показово, що Платон неодноразово вимагав в ім'я укріплення моралі та знищення розпусти усіляких обмежень і суворої регламентації в галузі музичної практики, аж до заборони певних ладів та музичних інструментів, а Арістотель, розвиваючи своє вчення про музичний етос, наголошував на етичних властивостях певних ладів, вважаючи найбільш вдалим для виховних цілей суворий і розмірений дорійський лад.

Подальша історія розвитку філософської думки неодноразово звертала увагу на взаємозв'язок художньої і моральної свідомості. Наприклад, романтики взагалі ототожнювали прекрасне з духовним як вищим проявом моралі, вершиною ж прекрасного для них завжди залишалось мистецтво. А їх натхненник I.В. Гете, спираючись на висновок I. Канта про красу як символ моральності, про прекрасне як природу, освітлену кінцевою моральною метою (Кант стверджує, що через красу «природа» немов би говорить ... дещо таке, що, здається, має вищий сенс»), з глибокою впевненістю наголошував на тому, що мистецтво органічно включає моральність і людина, яка володіє мистецтвом, водночас володіє і релігією.

XX століття підсумовує думку про моральнісну складову мистецтва словами Х. Ортеги-і-Гассета: «В мистецтві, як і в моралі, належне не залежить від нашого свавілля; залишається підкоритися тому імперативу, який диктує нам епоха» [6, с.236]. Ще категоричніший висновок Ж. Марітена: «... домен Мистецтва і домен Моралі складають два автономні світи, але всередині того ж людського субстрату. ... I оскільки художник є людина, перш ніж бути художником, автономний світ моралі безперечно вище (і ширше), ніж автономний світ мистецтва. Інакше говорячи, Мистецтво посереднім і зовнішнім чином підпорядковано Моралі» [4, с. 172 - 178].

Отже, мистецтво як морально осмислений світ культурного буття найповніше відповідає задачам формування духовно зрілої особистості, вищим рівнем якого $є$ виховання духовності. При цьому слід звернути увагу ще на одну специфічну характеристику мистецтва, що пояснює його духовно-виховні можливості-здатність виражати найглибші структури суб'єктивної реальності. Такі структури дуже важко, а то й просто неможливо передати засобами природної мови. Але існує особлива - художня мова, і митець, завдяки притаманній тільки йому здібності до об'єктивного опосередкування суб'єктивного відображення та вираження, об'єктивує те, що існуючий категоріальний апарат науки ще не дозволяє вербалізувати.

Саме мистецтво, художня творчість допомагає людям усвідомити, 
підняти з глибин своєї суб'єктивності і виразити структури, про наявність яких самі вони можуть і не здогадуватися, а також подолати переважання утилітарних інтересів над духовними. В цьому сенсі мистецька освіта набуває значення універсального засобу духовного виховання на всіх етапах розвитку людини. А відтак, художній універсалізм постає одним з основоположних принципів, завдяки яким мистецька освіта набуває пріоритетного значення у процесі духовного відродження України і виховання духовності.

Серед інших вагомих принципів слід відмітити спрямованість мистецької освіти на творчий саморозвиток особистості, що зумовлено залученням останньої до художньої діяльності як невід'ємної і дуже важливої складової мистецької освіти. Її важливість полягає, насамперед, в тому, що художня діяльність найвищою мірою відповідає змісту діалектичної категорії творчості, яка передбачає змінення об'єкта та самозмінення, саморозвиток суб'єкта як взаємопов'язані сторони єдиного культурного процесу. Здобутком творчості, її предметним результатом тут $є$ мистецтво. Щоб стати надбанням соціокультурного універсуму, потенціал художньої діяльності повинний втілитися у реально існуюче багатство культури - твори мистецтва.

Проте, не тільки та діяльність, яка завершується конкретним, очевидним результатом, може бути названа творчою. I на цю обставину слід звернути особливу увагу викладачам мистецьких дисциплін. Як «ціннісно-процесуальний феномен» (А.С. Канарський) творчість є цінністю як процес, незалежно від матеріально вираженого результату останнього. Адже зовсім не завжди творчі здібності та творча діяльність фіксуються предметно, результатом творчості може виступати i власний духовний розвиток особистості - збагачення їі внутрішнього світу, удосконалення її задатків, здібностей, обдарувань, здатності до спілкування, тобто усе, що детермінує подальшу творчу активність самої особистості та підвищує її значущість для себе та для інших.

Таким чином, художня творчість охоплює всю сферу суб'єктоб'єктних та суб'єкт-суб'єктних відносин, виступаючи тим самим найадекватнішим способом існування людини і відображаючи специфічне відношення «творча особистість - національно-культурний універсум», де етнокреативний фактор соціального буття є найближчим, безпосереднім аспектом її самотворення й творення культурного світу - національним «апріорі культури» як індивідуальним витоком її поліваріантності.

I так як джерелом творчості є особистість діяльного суб'єкта, то головним принципом формування художньо-творчого досвіду нації по- 
стає самодіяльність особистості, що створює себе та вибудовує культуpy і мистецтво в безперервному творчому акті самоздійснення.

При цьому сутність, зміст, сенс існування в суспільстві художньої діяльності характеризує саме те, що розвиток творчих сил людини $\epsilon$ у ній самоціллю. У цьому найповніше проявляються її творчі потенції та притаманні їй можливості брати участь не тільки у пізнанні, але й у перетворенні дійсності. Мистецтво $\epsilon$ засобом власного розвитку людини, бо у процесі художньої діяльності вона одночасно формує щось нове у собі, i насамперед,--здатність творити. Творча діяльність в мистецтві постає тому як самодіяльність, самозмінення, саморозвиток людини $\mathrm{i}$, навіть не усвідомлюючи цього, людина сама неначе перетворює себе у ціль своєї діяльності, об'єктивно виступаючи у цьому процесі як самоціль.

У підсумку слід зазначити, що виділення художнього універсалізму і спрямованості на творчий саморозвиток як основоположних принципів, завдяки яким мистецтво і мистецька освіта набувають пріоритетного значення у процесі духовного відродження України і виховання духовності, потребує подальшого поглиблення в дослідженні, адже кожний з них є потенційно необмеженим. Художній універсалізм гармонізує внутрішній світ людини, розширює межі її духовного збагачення, а спрямованість на творчий саморозвиток формує самодостатню, здатну до самовиховання і самоздійснення особистість, що найповніше відповідає сучасним вимогам особистісно орієнтованого навчання $\mathrm{i}$ виховання.

Відтак, саме мистецька освіта здатна забезпечити виконання духовно-творчої функції культури в сучасному вітчизняному суспільстві та найповніше сприяти прискоренню процесу духовного відродження,

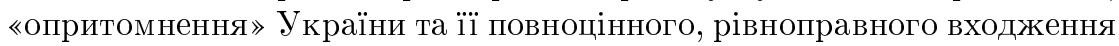
у європейське та світове співтовариство, включаючи і Болонський освітянський простір. Адже при всій важливості матеріальних здобутків, удосконалення техніки й технології, інформаційного озброєння головною умовою такого входження $\epsilon$ самодостатність і велич духу людини i нації-українця і українства, адже, як сказав ще Г. Сковорода, «плоть нічтоже, дух животворить».

\section{1 Бібліографія}

[1] Банфи А. О жизни искусства // Философия искусства.-М.: Искусство, 1989. - С. 36-40. 
[2] Даренсъкий B. «Мова» мистецтва як феномен екзистенційного діалогу // Людинознавчі студії: Зб. наук. праць ДДПУ. Філософія. - Дрогобич: Вимір, 2005.- С. 54-63.

[3] Лосев А.Ф. Диалектика художественной формы // ФормаСтиль - Выражение. - М.: Мысль, 1995.-C.321-404.

[4] Маритен Ж. Ответственность художника // Самосознание европейской культуры ХХ века: Мыслители и писатели Запада о месте культуры в современном обществе.-М.: Политиздат, 1991. C. 171-207.

[5] Національна доктрина розвитку освіти // Книга вчителя дисциплін художньо-естетичного циклу: Довідково-методичне видання / Упоряд. М.С.Демчишин; О.В. Гайдамака. - Харків: ТОРСІНГ ПЛЮС, 2006. - С. 28-42.

[6] Ортега-и-Гассет X. Дегуманизация искусства // Самосознание европейской культуры XX века: Мыслители и писатели Запада о месте культуры в современном обществе.- М.: Политиздат, 1991. - C. 230-263.

[7] Юнг К.Г. Психология и поэтическое творчество // Самосознание европейской культуры XX века: Мыслители и писатели Запада о месте культуры в современном обществе.-М.: Политиздат, 1991. - C. 103-129. 